\title{
Do policies and institutions matter for pre-tax income inequality? Cross-country evidence
}

\author{
Damián Vergara ${ }^{1}$
}

Accepted: 9 February 2021 / Published online: 16 March 2021

(C) The Author(s) 2021

\begin{abstract}
Do policies and institutions matter for pre-tax income inequality? I build an annual panel of 43 countries for the period 1980-2016 to document cross-country facts. I find robust correlations between pre-tax income shares and economic policyfinancial development, trade openness, government expenditure, and income taxation-even after controlling for economic development. I further find that proxies of institutional quality - e.g., state development, corruption, or political exclusionmediate the relationship between top income shares and economic policy, in particular for trade openness and government expenditure. The role of institutions in allowing or limiting rent-seeking can rationalize the results.
\end{abstract}

Keywords Inequality $\cdot$ Policies $\cdot$ Institutions

JEL Classification E6 $\cdot$ F6 $\cdot$ H5

\section{Introduction}

The availability of high-quality data on top income shares has revived an old debate: is income inequality an inevitable consequence of growth and globalization, or it is affected by domestic economic policies and institutions? ${ }^{1}$ Following the theory of marginal productivity, the first view claims that trends in pre-tax inequality are mainly explained by market forces, for example skill-biased technological change and "superstar effects" (e.g., Kaplan and Rauh 2013). The second view contests that argument suggesting that what governments do is more important. In words of

\footnotetext{
1 With high-quality data, I refer to (i) the use of tax data to improve measurement at the top of the income distribution (Blanchet et al. 2018), (ii) the availability of harmonized data that eases both crosscountry and time-series comparisons (Alvaredo et al. 2018), and (iii) the transition to an inequality measure based on income concentration at the top (Leigh 2007; Atkinson et al. 2011; Palma 2011).
}

Damián Vergara

damianvergara@berkeley.edu

1 Department of Economics, UC Berkeley, Berkeley, USA 
Alvaredo et al. (2013), "the fact that high-income countries with similar technological and productivity developments have gone through different patterns of income inequality at the very top supports the view that institutional and policy differences play a key role in these transformations." To the extent that countries care about inequality, understanding the role of policies and institutions is of prime relevance. ${ }^{2}$ However, empirical evidence in this regard is scarce. The measurement and identification challenges raised by this question make comprehensive analyses difficult. ${ }^{3}$

I aim to contribute to this debate by providing cross-country evidence on the relationship between pre-tax income inequality, economic policy, and institutions. I investigate whether economic policy systematically correlates with pre-tax inequality and explore the role of institutions in shaping these correlations, i.e., I study whether, conditional on its implementation, the quality of the institutions affect who are the winners and the losers of the different economic policies. I focus on the role of political institutions. Consequently, throughout the paper, the term institutional quality refers to institutional features that reflect their degree of inclusiveness (Acemoglu and Robinson 2012) as, for example, state development, corruption, or political exclusion.

To this end, I assemble a yearly panel of 43 countries for the period 1980-2016 with data on top income shares and different measures of economic policy, namely trade openness, government expenditure, financial development, and income taxation. The choice of the policy variables mainly follows Roine et al. (2009) which is, to my knowledge, the only paper that uses data on top income shares with similar purposes. As a starting point, I present OLS regressions of pre-tax income shares on economic policies that control for country and time fixed effects, as well as for other time-varying controls at the country-level. I find strong correlations between income inequality and economic policy after accounting for economic development. Openness to trade, government expenditure, and top marginal income tax rates are associated with smaller income shares of the richer $1 \%$ and larger income shares of the bottom $90 \%$. Conversely, financial development is positively related to income shares at the top at the expense of the rest of the population. These patterns are robust to different empirical models, sets of controls, and variable definitions.

I then explore the role of institutions in shaping the correlations between pre-tax income inequality and economic policy. Concretely, I inspect whether the inequality-policy correlations vary with institutional quality. While there is a vast literature that discusses how institutions interact with policy and inequality (e.g., Alesina et al. 2001; Acemoglu et al. 2015), to my knowledge, this question has not been

\footnotetext{
${ }^{2}$ Both views also have different normative implications. The market-based perspective proposes a link between inequality and merit, suggesting that the rich deserve their income share (Mankiw 2013). By contrast, if policies and institutions allow the rich to increase their incomes at the expense of the rest of the population, the link between income and merit is weakened (Stiglitz 2016).

3 Similar discussions exist in the related literature. Katz and Murphy (1992), Card and Lemieux (2001), Card and DiNardo (2002), Autor et al. (2003), and Autor et al. (2008) discuss the relative importance of technology and labor market institutions in explaining wage inequality trends. Zucman (2015) and Saez and Zucman (2019) discuss to what extent wealth tax evasion is a policy choice or a consequence of globalization.
} 
quantitatively explored beyond the reduced form evidence of Acemoglu et al. (2015) on the distributional effects of democracy.

I follow two strategies to test for heterogeneity in the relationship between policies and inequality. The first builds on the literature that argues that current institutions have their roots in pre-industrial features of the countries (Acemoglu et al. 2001; Acemoglu and Robinson 2012; Nunn 2009, 2020). I use Giuliano and Nunn (2018) country-level data on ancestral characteristics of modern populations and consider two variables that have been used as predictors of current institutions. The first is the level of jurisdictional hierarchies beyond the local community, which has been used as a predictor of state development (e.g., Gennaioli and Rainer 2007; Michalopoulos and Papaioannou 2013). Intuitively, ancestral groups that generated relationships with higher levels of political authorities developed more sophisticated forms of government in the long-run. The second is the proportion of the ancestors that preferred cousin marriage to non-cousin marriage, which has been used as a predictor of corruption and lack of political inclusiveness (e.g., Akbari et al. 2019; Schulz 2020). Intuitively, ancestral groups that preferred cousin marriage generated more closed social groups (and elites) that favored corruption in the long-run.

The second strategy uses the Varieties of Democracy (V-Dem) database that is a time-varying dataset that provides a series of indexes that aim to capture the multidimensional concept of democracy (Coppedge et al. 2020). This dataset contains several indicators that characterize different aspects of countries' institutions. I focus on three sets of indicators. The first measures different characteristics of the political regime - the prevalence of clientelism, the importance of hereditary succession in political power, and two measures of corruption. The second measures the degree of influence that different power groups - the aristocracy, the agrarian elites, the party elites, and the business elites-have on the political regime. The third measures the degree of political exclusion faced by different groups based on their observed characteristics-socioeconomic status, gender, political affiliation, and urban/rural status. ${ }^{4}$

Using a variety of institutional variables and different empirical strategies, the analysis consistently shows that institutions affect the inequality-policy correlations. In particular, I find that institutions are determining for the distributional consequences of openness to trade and government expenditure. In the presence of high-quality institutions, openness to trade and government expenditure are related to less inequality. However, low-quality institutions map trade into more inequality and make government expenditure ineffective for helping the bottom $90 \%$. Interestingly, the positive correlation between financial development and income inequality and the negative correlation between progressive taxation and income inequality are relatively stable along the institutional spectrum. While this setting inherently does

\footnotetext{
4 This dataset is gaining popularity in the political science literature (e.g., Coppedge et al. 2016; Bernhard et al. 2017; Lührmann et al. 2018; Lührmann and Lindberg 2019; Rocabert et al. 2019) but its influence in economics is still limited (e.g., Alesina et al. 2017). The increase of V-Dem's popularity is partly explained by the criticisms received by other measures of democracy (Cheibub et al. 2010), as well as by the call for more continuous and multidimensional measures of democracy (Elkins 2000). For a discussion, see Munck and Verkuilen (2002).
} 
(a) Policies for which institutions mediate correlations
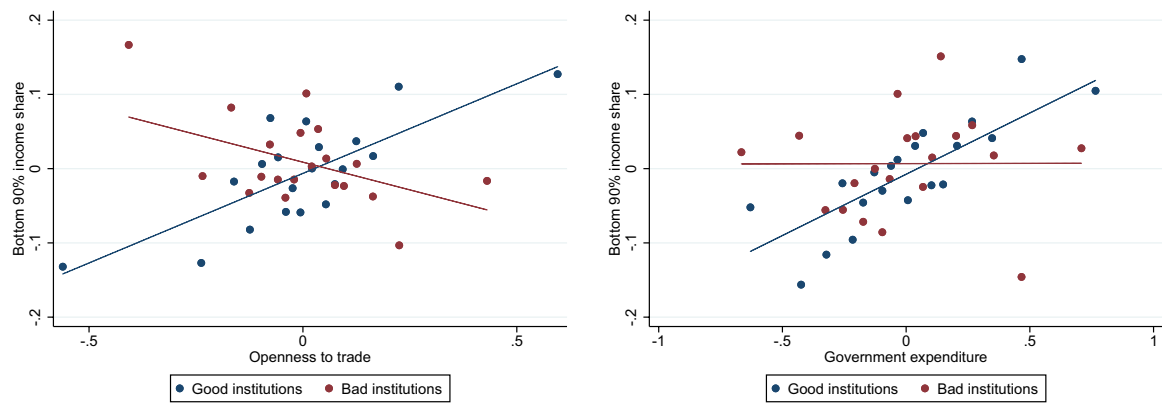

(b) Policies for which institutions do not mediate correlations
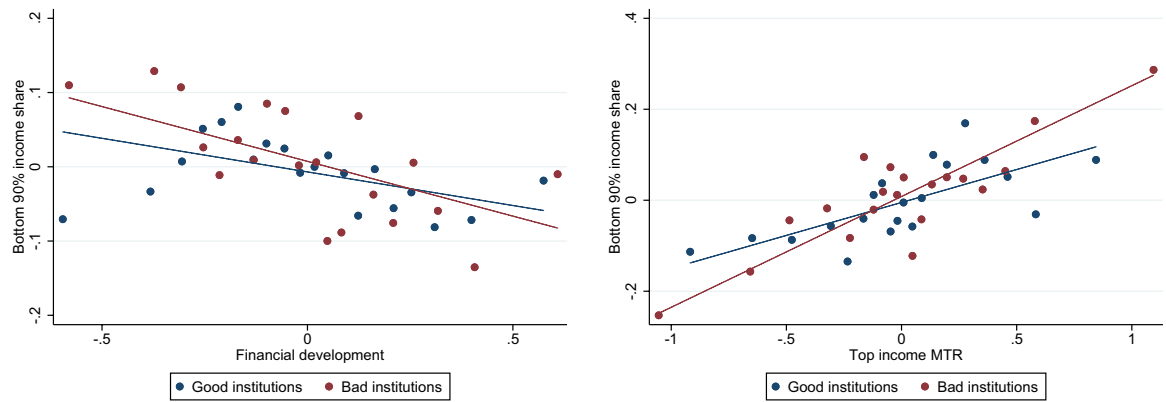

Fig. 1 Partial correlations between bottom 90\% income share and economic policy. Notes: Each figure plots the income share of the bottom $90 \%$ against a measure of economic policy, separately by institutional quality. Variables are standardized within the estimation sample. Figures control for country and time fixed effects, GDP per capita, population, and the rest of the policy measures. The institutional index is created as follows. First, I sum the following standardized V-Dem indices: regime corruption, influence of business elites, and degree of political exclusion by gender. I then standardize the sum. Finally, I label country-time points as Good institutions (Bad institutions) when the composite index is negative (positive). For details on the policy variables, see Sect. 2. For details on the institutional variables, see Sects. 2 and 4

not lend itself to inference from cleanly identified natural experiments and certainly does not capture all channels through which institutions, policy, and inequality are interrelated, I argue that the weight of evidence from a battery of panel regressions supports the claim that political institutions meaningfully affect the robust relationship between domestic economic policies and income inequality. Consistent with Helpman (2017), this suggests that globalization cannot be the only factor responsible for the recent increase in income inequality.

Figure 1 provides a concise summary of the regressions. Following Kling et al. (2007) and Chetty et al. (2011), each figure plots the (standardized) income share of the bottom $90 \%$ against a (standardized) measure of economic policy separately by institutional quality (measured as a compounded standardized index based on the V-Dem variables). The partial correlations control for country and time fixed effects, 
GDP per capita, population, and the rest of the policy measures. The plots show that openness to trade and government expenditure benefit the bottom $90 \%$ only when institutions are high quality. They also show that financial development and income taxation strongly correlate with inequality regardless of the institutional variables.

I end the paper by proposing a narrative for rationalizing the results. I argue that one channel through which institutions may affect the inequality-policy correlations is by allowing (or limiting) rent-seeking activities by the rich. This narrative is consistent with several papers that give a central role to rent-seeking in shaping the upper tail of the income distribution (e.g., Bivens and Mishel 2013; Lazonick and Mazzucato 2013; Piketty et al. 2014; Stiglitz 2016; Haselmann et al. 2018). Certainly, the empirical results presented in the paper lack the necessary causal interpretation to be informative about mechanisms. However, my objective is to stress the importance of incorporating institutions in optimal policy analysis. If we accept that institutions matter for the mapping between economic policy and inequality, then optimal policy problems should allow social planners to affect institutions together with standard policy choices.

The rest of the paper is structured as follows. Section 2 describes the data. Section 3 presents the baseline results between economic policy and inequality. Section 4 explores the role of institutions in shaping the policy-inequality correlations. Finally, Sect. 5 briefly discusses the rent-seeking narrative that is consistent with the results and concludes.

\section{Data}

\subsection{Inequality}

I measure inequality using data on pre-tax national income shares from the World Inequality Database (WID; see Alvaredo et al. 2018). As in Roine et al. (2009), I distinguish between three income groups: the income share of the richer $1 \%$ denoted topl-, the income share of the rest of the top decile-denoted top 10-, and the income share of the rest of the population-denoted bot 90 -, with top $1+\operatorname{top} 10+\operatorname{bot} 90=100$. I also compute the ratio top $1 \% /$ top $10 \%$ that measures within top decile inequality. The WID assigns a score (from 0 to 5) to each country depending on the quality of the data. I only consider countries with scores of 3 or more, which are countries that use tax data to improve the income shares computations. ${ }^{5}$

\footnotetext{
${ }^{5}$ For some country-year combinations, there is only data for the income share of the top $1 \%$. To use the same sample across regressions, I exclude those observations from the sample. The results are robust to including them.
} 


\subsection{Economic policies}

The policies considered are openness to trade, government expenditure, financial development, and top marginal income tax rates. The choice of these policies is twofold. First, these are the variables considered by Roine et al. (2009). Since this paper builds on their results, I intend to make results comparable. Second, other relevant policies lack reliable global datasets. For example, there is no harmonized dataset on labor market regulations (e.g., minimum wages or unionization rates) with good coverage. ${ }^{6}$

Openness to trade is measured as imports plus exports as a share of GDP and is taken from the World Development Indicators (WDI). Government expenditure is measured as central government consumption as a share of GDP and is also taken from the WDI. Financial development is measured by the Financial Development Index developed by the IMF (Sahay et al. 2015). This index measures the depth, access, and efficiency of financial institutions and financial markets. Finally, I gather information on top marginal income tax rates from different sources. The main sources are Piketty et al. (2014), Londoño-Vélez (2014), the World Tax Indicators database (ICEPP 2010), and Roine et al. (2009). Whenever consistent, I update those series to more recent years using OECD Taxing Wages statistics and Trading Economics data. For some countries and periods, data are complemented using country-specific sources. For details about the specific sources used for each country, see Table A.1 of Online Appendix A.

\subsection{Institutions}

I include several variables that proxy for institutional quality. I consider both predetermined (ancestral) and time-varying (contemporary) variables. In this section, I describe the datasets. The specific variables used are discussed in Sect. 4.

The first set of institutional variables is taken from Giuliano and Nunn (2018). The authors build a country-level dataset of pre-industrial information of the ancestors of each country based on the Ethnographic Atlas and complemented by data collections on Eastern European, Western European, and Siberian ethnic groups. The authors collapse the data to the country-level using the dialects and languages spoken by the different ethnic groups. Some of these variables have been found to predict current institutional features. I use them for characterizing the idiosyncratic institutional component of countries. Alternatively, they can be interpreted as a measure of initial conditions.

The second set of institutional variables is taken from the Varieties of Democracy (V-Dem) database (Coppedge et al. 2020). This database provides a series of indexes that aim to capture the multidimensional concept of democracy. V-Dem distinguishes between different notions of democracy and builds high-level indexes to approximate them by combining several indicators. The last version contains more

\footnotetext{
${ }^{6}$ A fair critique is that openness to trade and financial development are broad variables that could be measuring different things depending on the country and their institutions. This is a caveat of my results.
} 
Table 1 Descriptive statistics

\begin{tabular}{lllllll}
\hline Variable & Obs. & Mean & SD & p25 & Median & p75 \\
\hline Top 1\% inc. share & 1228 & 10.83 & 4.34 & 8.11 & 9.91 & 12.16 \\
Top 10-1\% inc. share & 1228 & 23.68 & 3.83 & 21.22 & 22.85 & 25.36 \\
Bottom 90\% inc. share & 1228 & 65.49 & 7.26 & 62.76 & 67.38 & 70.06 \\
Top 1/10 ratio & 1228 & 0.45 & 0.14 & 0.35 & 0.43 & 0.52 \\
Openness to trade & 1228 & 84.00 & 66.29 & 48.34 & 64.92 & 97.85 \\
Government expenditure & 1228 & 18.30 & 3.99 & 15.87 & 18.64 & 20.83 \\
Financial development & 1228 & 0.55 & 0.19 & 0.40 & 0.55 & 0.71 \\
Top income MTR & 1228 & 44.82 & 13.02 & 39.00 & 45.00 & 52.00 \\
GDP per capita & 1228 & 26418.00 & 14040.83 & 16897.50 & 25153.00 & 35164.00 \\
Population & 1228 & 97120.67 & 255809.77 & 5241.00 & 10885.00 & 56867.50 \\
\hline
\end{tabular}

Variables definitions and sources are described in Sect. 2

than 470 different indicators. While the focus of the V-Dem project is the measurement of democracy, several of the inputs needed for building the democracy indexes explicitly refer to institutional features of the countries.

\subsection{Additional controls}

In all the regressions, I control for GDP per capita and population. I take these variables from the Maddison Project Database (Bolt et al. 2018).

\subsection{Discussion}

Focusing on the period 1980-2016 has advantages and disadvantages. One caveat is that the period can be considered short for the question in purpose since inequality is very persistent and has been found to have long-run roots (Milanovic et al. 2011; Piketty 2020). In fact, when running an OLS regression of the top $1 \%$ income share versus country fixed effects in my estimation sample, the adjusted R-squared is 0.77 . Since my empirical exercises consider country and time fixed effects, the identification comes from within-country across-time variation. Given that, the short-run persistence of inequality works against finding any significant correlation.

On the other hand, focusing on a more recent period has some advantages. First, it avoids using periods with world wars, which are atypical in terms of their inequality dynamics (Piketty 2014). Second, it allows me to work with harmonized and better quality data. Consequently, this strategy implies a larger sample size and, therefore, is more suitable for heterogeneity analyses. This also adds external validity to the analysis. Given this, I see this paper as complementary to Roine et al. (2009). One advantage of their analysis is the longer period. However, they work with a 
Table 2 Inequality and policy: correlations

\begin{tabular}{lllll}
\hline & Top1 & Top10 & Bot90 & Top1/10 \\
\hline Openness to trade & $-1.045 *$ & 0.218 & 0.827 & $-0.0504 * *$ \\
& $(0.575)$ & $(0.414)$ & $(0.907)$ & $(0.0202)$ \\
Government expenditure & $-0.979 * * *$ & 0.454 & 0.524 & $-0.0453 * * *$ \\
& $(0.257)$ & $(0.357)$ & $(0.464)$ & $(0.0111)$ \\
Financial development & $0.829 * *$ & 0.0468 & -0.876 & $0.0384 * *$ \\
Top income MTR & $(0.375)$ & $(0.404)$ & $(0.690)$ & $(0.0125)$ \\
& $-0.903 * * *$ & $-0.620 * * *$ & $1.523 * * *$ & $-0.0283 * *$ \\
Observations & $(0.272)$ & $(0.188)$ & $(0.301)$ & $(0.0117)$ \\
Adjusted $R^{2}$ & 1228 & 1228 & 1228 & 1228 \\
\hline
\end{tabular}

All regressions are estimated by OLS and include country and time fixed effects and control for GDP per capita and population. Each column is a separate regression. (The column title is the dep. variable.) For details on the variables and the estimation sample, see Sect. 2. Standard errors (in parentheses) are clustered at the country level

$* p<0.10, * * p<0.05, * * * p<0.01$

smaller set of countries that restrict the heterogeneity analysis and induces additional empirical concerns. ${ }^{7}$

\subsection{Descriptive statistics}

The estimation sample contains 43 countries. The panel is unbalanced. Countries have, on average, 28 observations. Table A.1 in Online Appendix A shows the list of countries considered with the corresponding periods used in the estimations. Developed countries are overrepresented in the sample, which is not surprising given the data requirements. Since I estimate regressions with country fixed effects and, therefore, identification comes from within-country across-time variation, sample selection should not be an important concern for the validity of the results. Table 1 shows the descriptive statistics for the estimation sample. The average observation has top $1 \%$, top $10 \%$, and bottom $90 \%$ income shares of $10.83 \%, 23.68 \%$, and $65.49 \%$, respectively. Also, for the average observation, imports plus exports represent $84 \%$ of GDP, government consumption is $18.3 \%$ of GDP, the financial development index is 0.55 , the top marginal income tax rate is $44.82 \%$, the GDP per capita (in 2011 dollars) is 26,418 , and the population is 97 million.

\section{Starting point: income inequality and economic policy}

Empirical model The baseline model is a standard cross-country regression with fixed effects:

\footnotetext{
7 Their descriptive analysis considers 16 countries for the period 1900-2000, but because of data limitations, their regressions use 5-year averages for only 12 countries for the 1950-2000 period.
} 


$$
y_{c t}=X_{c t}^{\prime} \beta+\gamma_{c}+\gamma_{t}+\epsilon_{c t},
$$

where $c$ indexes countries, $t$ indexes years, $y_{c t}$ is an income share variable (topl, top 10, bot 90 , or the ratio top 1\%/top $10 \%$ ), $X_{c t}$ is the vector of policies and controls, and $\gamma_{c}$ and $\gamma_{t}$ are country and time fixed-effects. To ease the interpretation of the estimated coefficients, $y_{c t}$ is included in levels and all variables in $X_{c t}$ are standardized within the estimation sample. Equation (1) is estimated by OLS and standard errors are clustered at the country level.

I do not claim causality in any of the estimated regressions. There are reasons to think that policies are endogenous to inequality or that there are relevant omitted variables that simultaneously affect both. ${ }^{8}$ Since I lack plausible exogenous variation in policy determination, I focus on just exploring whether there are significant correlations between $y_{c t}$ and $X_{c t}$ after controlling for country and time fixed effects. As motivated in the introduction, even in the absence of causal inference, the quantitative exploration of significant correlations is a relevant and non-trivial question.

Results Table 2 presents the results. They show that economic policy correlates with pre-tax income inequality after controlling for country and time fixed effects, GDP per capita, and population. ${ }^{9}$ Openness to trade and government expenditure are correlated with lower income shares at the top with a corresponding increase in top $10 \%$ and bottom $90 \%$ income shares. Financial development is positively correlated with the top $1 \%$ income share with a corresponding decrease in the bottom $90 \%$ income share. Finally, the top marginal income tax rate is strongly correlated with lower income shares for the top $1 \%$ and top $10 \%$ and larger shares for the bottom $90 \%$. Moreover, all policies significantly affect within top decile inequality. Coefficients are, in most cases, economically and statistically significant.

These results are consistent with Roine et al. (2009) findings. They find similar significant results for financial development and income taxation, as well as relatively noisier effects for trade openness and government expenditure. This is important since the countries and time period considered are different, as well as the estimation techniques.

Robustness checks Acknowledging the problems of cross-country regressions, I perform several robustness checks to my main specification. The results are presented in Online Appendix B.

Serial correlation in the error term is likely to be a concern in cross-country regressions. I prefer the OLS specification with clustered standard errors since it is a more transparent methodology. However, I consider empirical models that explicitly deal with serial correlation in the error term. Table B.1 estimates a FGLS model that accommodates heteroskedasticity and panel-specific serial correlation. Table B.2 includes the lagged dependent variable and estimates a dynamic panel (Arellano-Bond). Table B.3 estimates the model in differences, allowing to control for country-specific time trends. While noisier (especially, the dynamic panel results, as expected), overall patterns hold under these alternative specifications.

\footnotetext{
${ }^{8}$ For a critical discussion on cross-country policy regressions, see Rodrik (2012).

${ }^{9}$ GDP per capita shows no correlation with inequality after controlling for the policy variables.
} 
Another concern is that cross-country regressions are sensitive to controls and samples (e.g., Levine and Renelt 1992; Sala-I-Martin 1997). Table B.4 includes region-time fixed effects, with regions defined using the geographical classification of the World Bank. Table B.5 controls for GDP per capita squared. Table B.6 controls for democracy, using Acemoglu et al. (2019) measure. Table B.7 uses an alternative GDP per capita measure (also taken from the Maddison Project Database). Tables B.8 and B.9 use alternative definitions of financial development, the ChinnIto index (Chinn and Ito 2006) and the sum of stock market capitalization and total deposits as a share of GDP, taken from the WDI. Table B.10 considers data from 1992 onwards. Table B.11 excludes countries with less than 10 observations. The results hold under these alternative specifications, some of them being slightly less precise given the addition of controls and the reduction of the sample size.

\section{Do institutions matter for inequality?}

The previous section documented that economic policy correlates with pre-tax income inequality. This finding is consistent with previous literature. I now explore whether institutions affect these correlations. Intuitively, countries with better institutions should be more effective in preventing the richer groups to disproportionately appropriate the rents from globalization and in designing and enforcing redistributive policies. Of particular interest are openness to trade and government expenditure, since their smaller precision in the estimated correlations could be driven by institutional heterogeneity. I use two sources of institutional data to address this question.

Predetermined variables I take two predetermined institutional variables from Giuliano and Nunn (2018) dataset: the level of jurisdictional hierarchies beyond the local community (henceforth, JH), and the preference for cousin marriage (henceforth, CM). As discussed in the introduction, these variables have been found to predict modern state development and corruption, respectively. Then, I assume that the quality of current institutions is increasing in $\mathrm{JH}$ and decreasing in $\mathrm{CM}$.

I refer to these variables as predetermined since they are measured in pre-industrial periods and, therefore, are exogenous and fixed at the country-level. Since regressions control for country fixed effects, I do not include these variables directly in the regressions. Instead, among all countries with non-missing data in the ancestral database ( 211 for $\mathrm{JH}, 198$ for $\mathrm{CM}$ ), I standardize the variables and then estimate Eq. (1) separately for countries with values above and below $0 .{ }^{10}$

Table 3 presents the results of this exercise. Panel A shows the results after splitting the sample using the JH variable. The results are noisier given the smaller sample sizes. Despite that, the analysis supports the presence of heterogeneities. The

\footnotetext{
10 A legitimate concern is that both variables capture the same variation and, therefore, I could be spuriously performing the same exercise twice. That would be the case if the countries with negative JH also have positive CM. While both variables are correlated, $23 \%$ of the countries (10/43) have JH and CM measures with the same sign. Then, there is variation to exploit between both variables.
} 
Table 3 Heterogeneity by predetermined institutional variables

Panel A: Jurisdictional hierarchies (JH)

\begin{tabular}{|c|c|c|c|c|c|c|c|c|}
\hline & \multicolumn{4}{|l|}{ Low JH } & \multicolumn{4}{|l|}{ High JH } \\
\hline & Top1 & Top10 & Bot 90 & Top1/10 & Top 1 & Top10 & Bot 90 & Top1/10 \\
\hline \multirow[t]{2}{*}{ Op. to trade } & 1.402 & 1.224 & -2.626 & 0.0295 & $-1.679 * * *$ & -0.177 & $1.856 * *$ & $-0.0691 * * *$ \\
\hline & $(0.713)$ & (0.859) & $(1.431)$ & $(0.0219)$ & $(0.517)$ & $(0.344)$ & $(0.744)$ & $(0.0193)$ \\
\hline \multirow[t]{2}{*}{ Gov. exp. } & 0.452 & $1.582 * *$ & -2.034 & -0.00973 & $-1.259 * * *$ & 0.204 & $1.054 * *$ & $\begin{array}{c}-0.0518 \\
* * *\end{array}$ \\
\hline & $(0.732)$ & $(0.538)$ & (1.136) & $(0.0229)$ & $(0.270)$ & $(0.338)$ & $(0.415)$ & $(0.0125)$ \\
\hline \multirow[t]{2}{*}{ Fin. dev. } & $1.691 * * *$ & -0.277 & $-1.414 * * *$ & $0.0833 * *$ & 0.438 & -0.289 & -0.149 & $0.0273 *$ \\
\hline & $(0.290)$ & $(0.461)$ & $(0.280)$ & $(0.0216)$ & $(0.432)$ & $(0.376)$ & $(0.706)$ & $(0.0145)$ \\
\hline \multirow{2}{*}{$\begin{array}{c}\text { Top inc. } \\
\text { MTR }\end{array}$} & $-1.724 * *$ & $-1.079 * * *$ & $2.802 * * *$ & $-0.0567 * *$ & $-0.889 * * *$ & $-0.530 * *$ & $1.419 * * *$ & $-0.0293 * *$ \\
\hline & $(0.439)$ & $(0.254)$ & $(0.667)$ & $(0.0141)$ & $(0.275)$ & $(0.206)$ & $(0.310)$ & $(0.0120)$ \\
\hline $\begin{array}{l}\text { Observa- } \\
\text { tions }\end{array}$ & 135 & 135 & 135 & 135 & 1093 & 1093 & 1093 & 1093 \\
\hline Adjusted $R^{2}$ & 0.879 & 0.848 & 0.873 & 0.849 & 0.916 & 0.914 & 0.934 & 0.863 \\
\hline
\end{tabular}

Panel B: Cousin marriage (CM)

\begin{tabular}{|c|c|c|c|c|c|c|c|c|}
\hline & \multicolumn{4}{|l|}{ Low CM } & \multicolumn{4}{|l|}{ High CM } \\
\hline & Top1 & Top10 & Bot90 & Top1/10 & Top 1 & Top10 & Bot90 & Top1/10 \\
\hline \multirow{2}{*}{$\begin{array}{l}\text { Op. to } \\
\text { trade }\end{array}$} & $-1.297 *$ & 0.156 & 1.141 & $-0.0594 * *$ & 0.956 & 0.654 & -1.611 & 0.0134 \\
\hline & $(0.646)$ & $(0.505)$ & (1.037) & $(0.0225)$ & $(1.214)$ & $(1.525)$ & $(2.634)$ & $(0.0227)$ \\
\hline \multirow[t]{2}{*}{ Gov. exp. } & $-1.066 * * *$ & 0.665 & 0.401 & $-0.0529 * * *$ & $-1.095 *$ & -1.172 & $2.267 *$ & -0.0162 \\
\hline & $(0.336)$ & $(0.412)$ & $(0.548)$ & $(0.0146)$ & $(0.483)$ & $(0.728)$ & (1.097) & $(0.0169)$ \\
\hline \multirow[t]{2}{*}{ Fin. dev. } & 0.428 & -0.182 & -0.246 & $0.0263 * *$ & $2.603 * *$ & 1.397 & $-4.000 * *$ & $0.0840 * * *$ \\
\hline & $(0.354)$ & $(0.463)$ & $(0.731)$ & $(0.0117)$ & $(0.754)$ & $(0.774)$ & $(1.432)$ & $(0.0197)$ \\
\hline \multirow{2}{*}{$\begin{array}{c}\text { Top inc. } \\
\text { MTR }\end{array}$} & $-0.916 * * *$ & $-0.698 * * *$ & $1.614 * * *$ & $-0.0281 *$ & -0.445 & -0.625 & 1.070 & -0.0113 \\
\hline & $(0.318)$ & $(0.181)$ & $(0.302)$ & $(0.0139)$ & $(0.594)$ & $(0.526)$ & $(0.946)$ & $(0.0216)$ \\
\hline $\begin{array}{l}\text { Observa- } \\
\text { tions }\end{array}$ & 989 & 989 & 989 & 989 & 239 & 239 & 239 & 239 \\
\hline $\begin{array}{l}\text { Adjusted } \\
R^{2}\end{array}$ & 0.918 & 0.886 & 0.928 & 0.865 & 0.883 & 0.922 & 0.910 & 0.851 \\
\hline
\end{tabular}

All regressions are estimated by OLS and include country and time fixed effects and control for GDP per capita and population. $J H$ refers to jurisdictional hierarchies, $C M$ to cousin marriage, $O p$. to trade to openness to trade, Gov. exp. to government expenditure, Fin. dev. to financial development, and Top inc. MTR to top income marginal tax rate. Each column is a separate regression. (The column title is the dep. variable.) For details on the variables and the estimation sample, see Sect. 2. Standard errors (in parentheses) are clustered at the country level

$* p<0.10, * * p<0.05, * * * p<0.01$

correlation between openness to trade and inequality flips sign between samples: while trade is correlated with more inequality in countries with low $\mathrm{JH}$, it benefits the bottom $90 \%$ income share when $\mathrm{JH}$ is high. A similar pattern is seen in 
government expenditure: it only seems to help the bottom $90 \%$ when institutions are good according to this measure. Also, while financial development is strongly correlated with inequality in countries with low values of $\mathrm{JH}$, this correlation decreases substantially (and loses statistical precision) in the sample with high JH. Finally, the negative correlation between the top marginal income tax rate and inequality holds for both samples. Panel B shows the results after splitting the sample using the $\mathrm{CM}$ variable. Regressions show similar patterns for openness to trade and financial development. However, while government expenditure is negatively correlated with inequality in both samples, the top marginal income tax rate has a significant negative correlation with inequality only in countries with low values of CM. When CM is high, the correlation is attenuated and less precise.

These results suggest that institutions affect pre-tax inequality through the consequences of economic policy. Good institutions help to map openness to trade into more equality rather than more inequality, make redistributive policy more effective, and attenuate the pro-inequality effect of financial development. Since these regressions (i) rely on long-run institutional measures that can be imprecise, and (ii) reduce the sample sizes of the estimations, I complement them by using a different source of institutional data and a corresponding different empirical strategy.

Time-varying variables I consider three sets of time-varying institutional variables from the V-Dem database. The first contains indicators that characterize the political regime. I consider the following indicators: the Clientelism index, that answers "to what extent are politics based on clientelistic relationships?", 11 the Hereditary index, that answers "to what extent is the power base of the chief executive determined by hereditary succession?", and two indexes of corruption, the Regime corruption index and the Political corruption index. The second set of indicators measures the degree of influence that different social groups have on the political system ("if the group were to retract support, it would substantially increase the chance that the regime would lose power?"). I consider the aristocracy, the agrarian elites, the party elites, and the business elites. Finally, the third set of indicators measures the degree of political exclusion by socio-economic status, gender, political affiliation, and urban status. ${ }^{12}$ All these indicators are decreasing in institutional quality.

Since these indicators are time-varying, I test for institutional heterogeneity by adding interactions with the policy measures, estimating the following modified version of Eq. (1):

$$
y_{c t}=X_{c t}^{\prime} \beta+\delta \cdot I_{c t}+\left(X_{c t} \cdot I_{c t}\right)^{\prime} \phi+\gamma_{c}+\gamma_{t}+\epsilon_{c t}
$$

where $I_{c t}$ is an institutional variable. I standardize these variables within the estimation sample. A valid concern is that these variables may be strongly correlated among themselves. If that was the case, all regressions would be using the same

\footnotetext{
11 V-Dem defines clientelistic relationships as including "the targeted, contingent distribution of resources (goods, services, jobs, money, etc.) in exchange for political support."

12 V-Dem defines political exclusion as "when individuals are denied access to services or participation in governed spaces based on their identity or belonging to a particular group."
} 


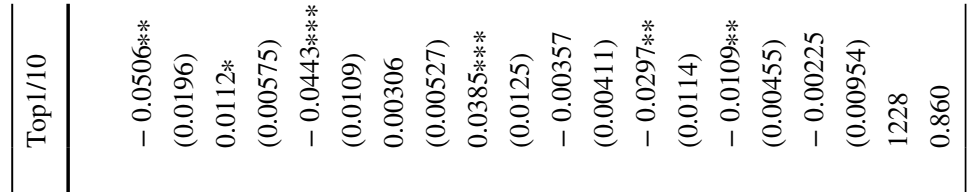

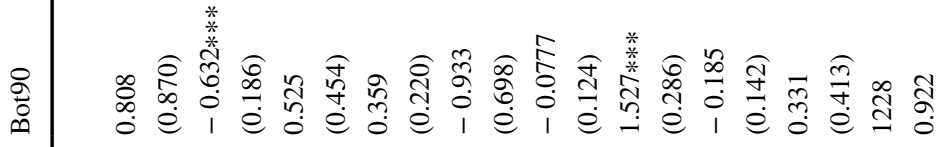

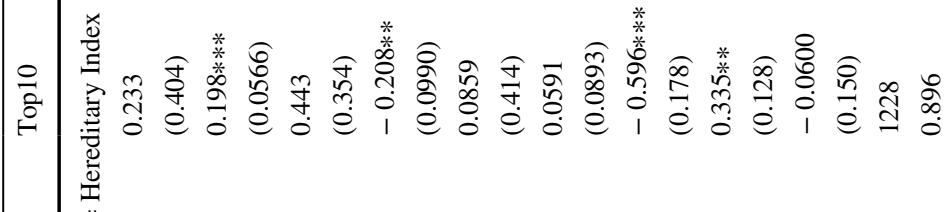

离

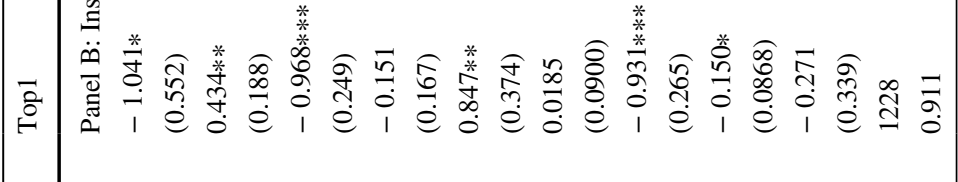

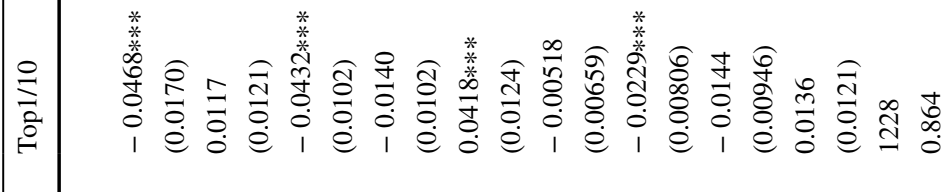

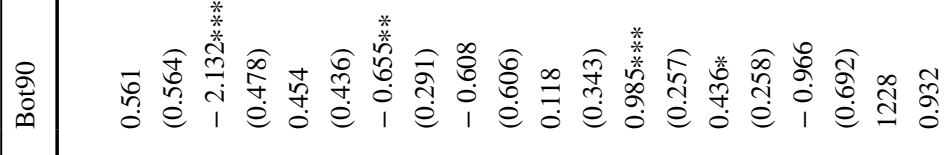

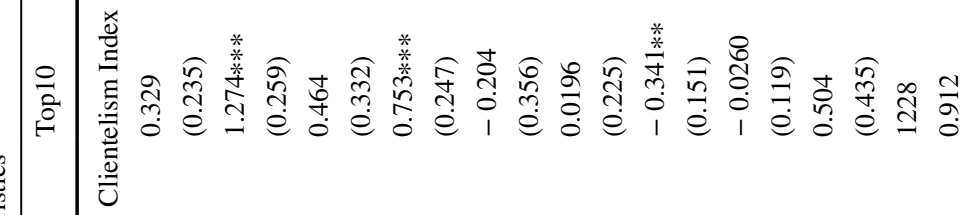

莺苞

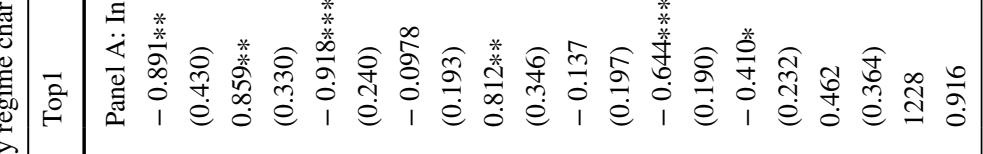

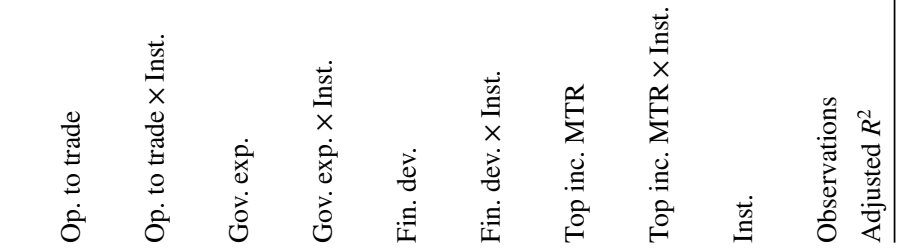




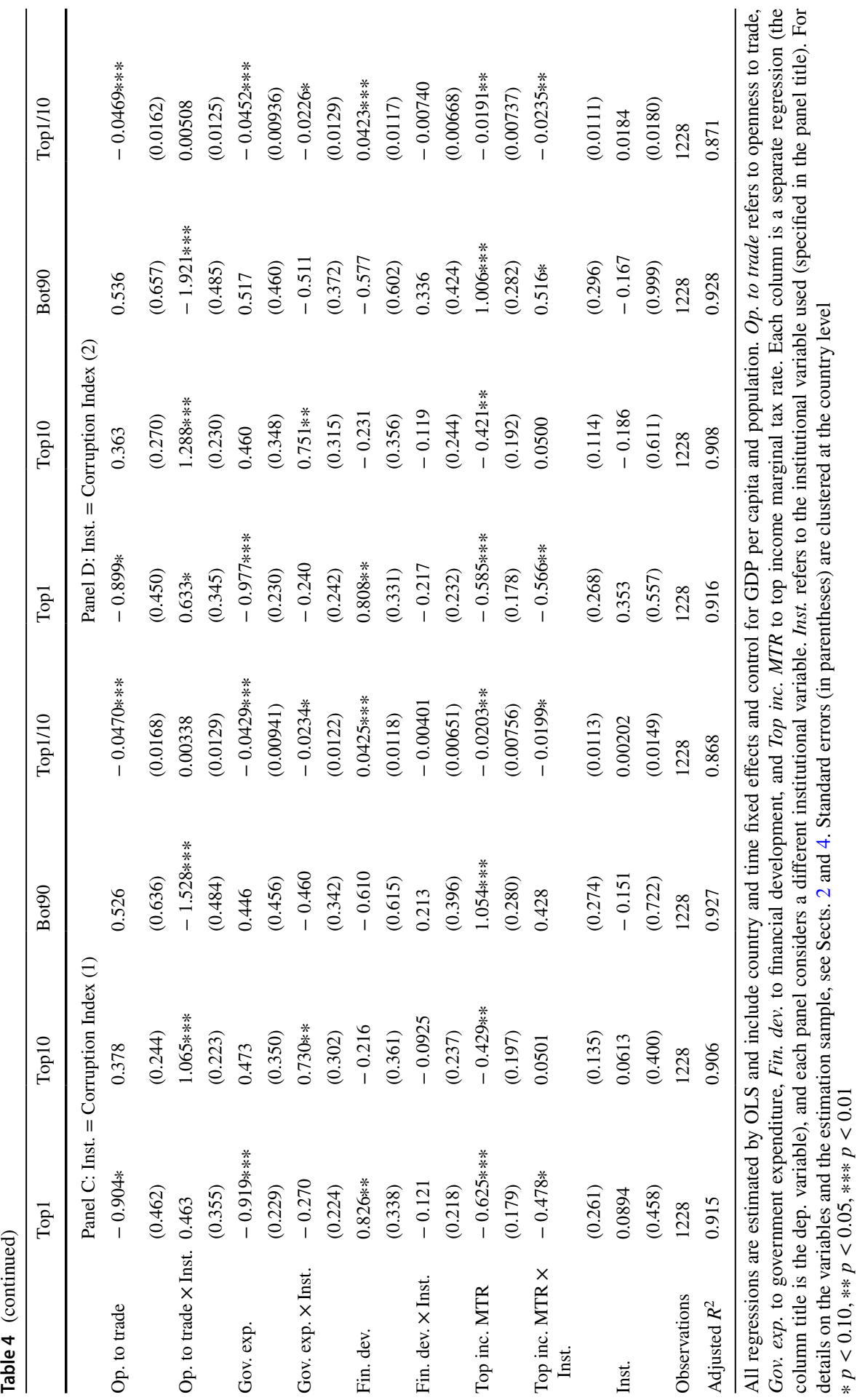




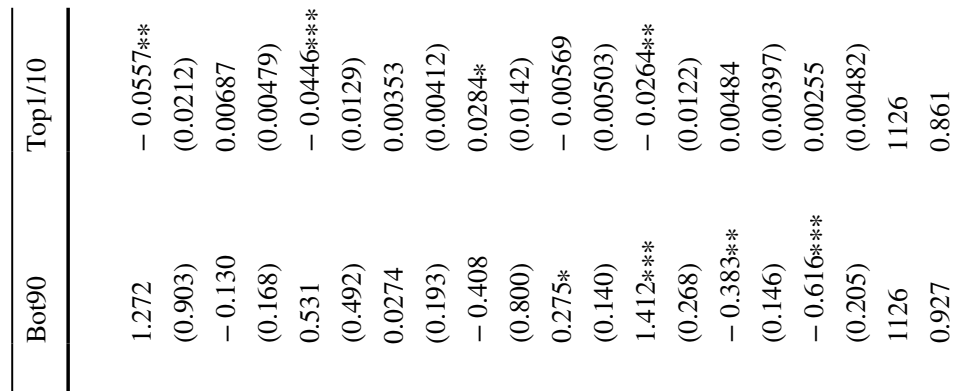

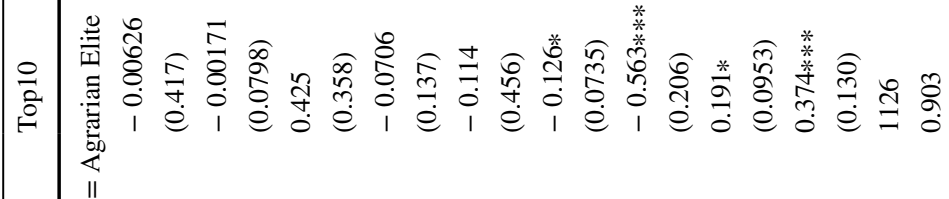

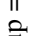

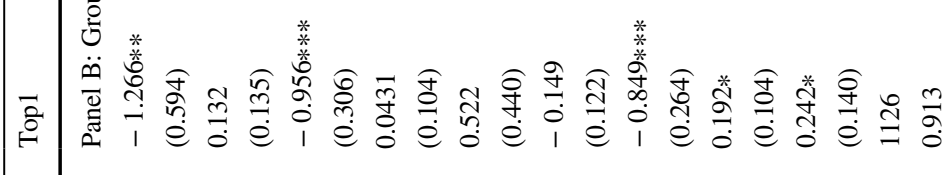

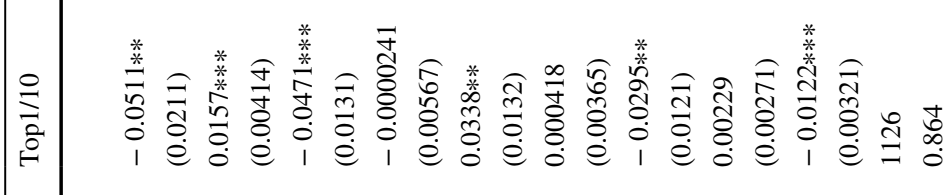

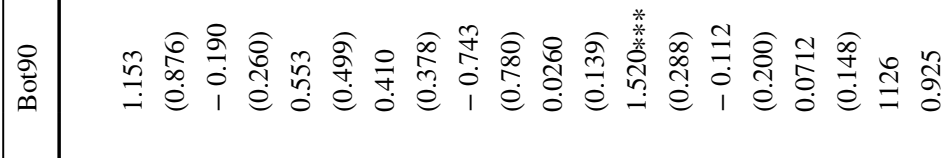

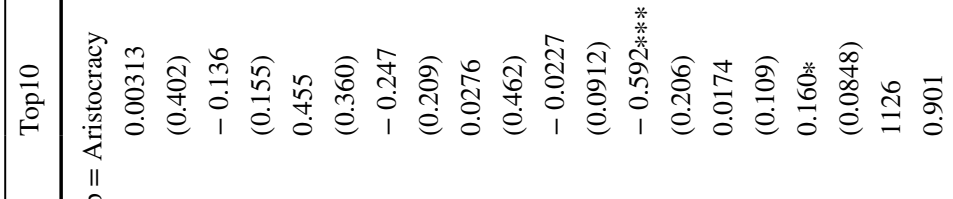

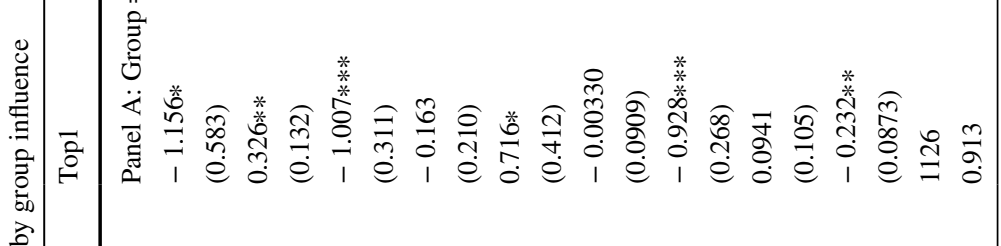

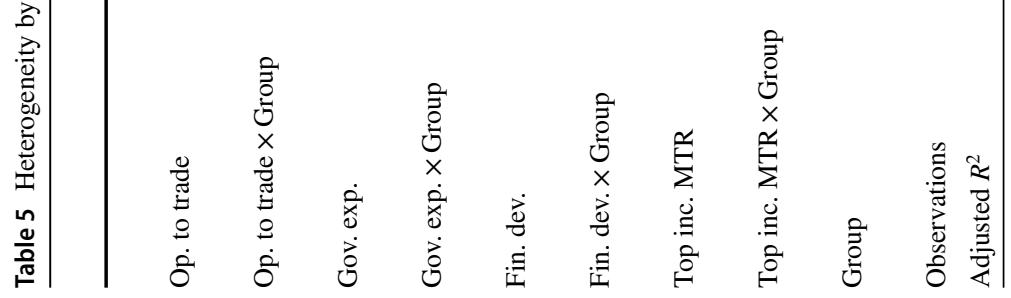




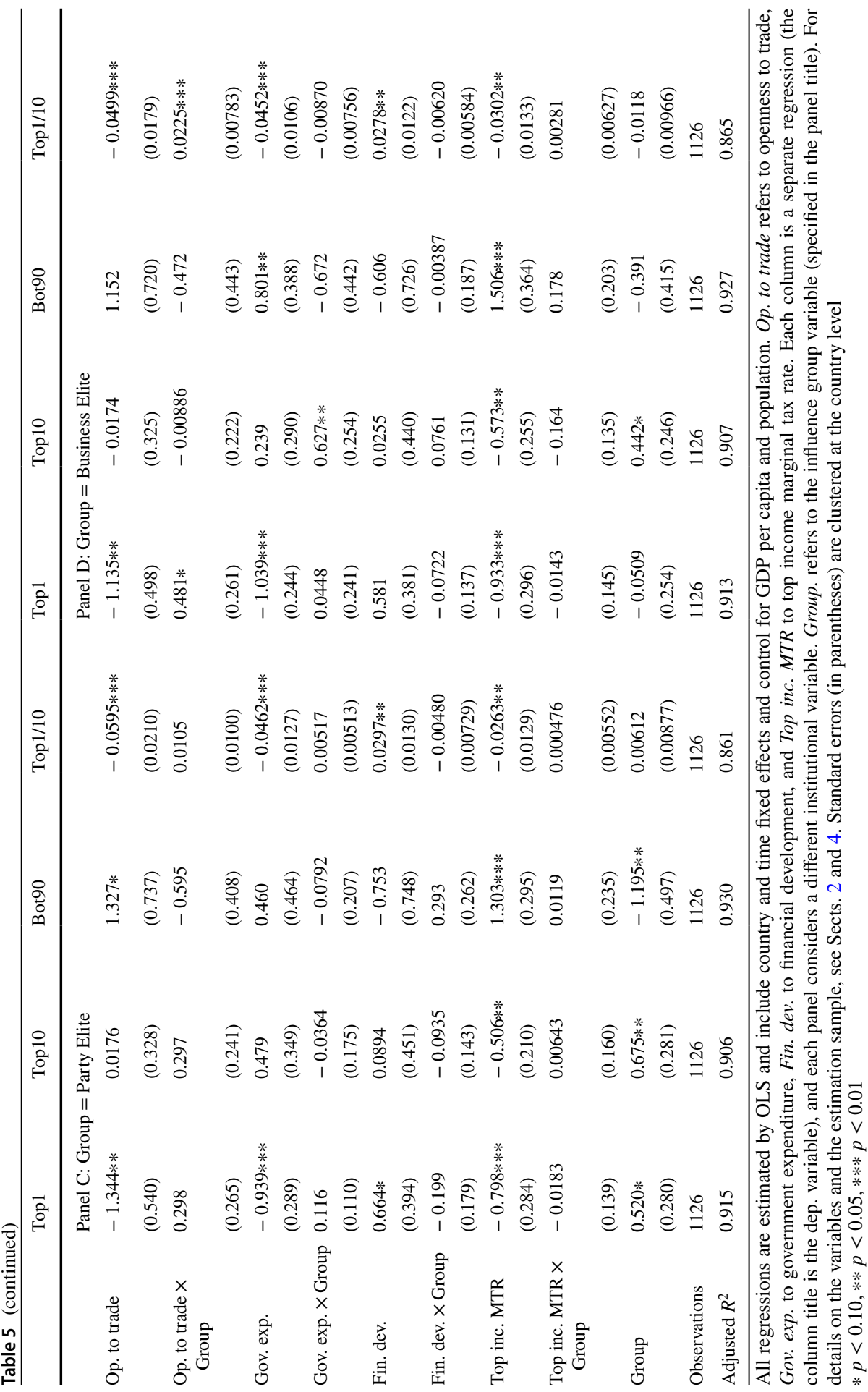


variation. While it is true that these indicators are correlated, two things are worth mentioning. First, as is shown in Table B.12 of Online Appendix B, correlation is not perfect (and is even absent or negative in some cases). Then, there is variation to exploit between the indicators. Second, to the extent that institutions matter, the fact that these measures are correlated stresses even more their importance. Comovement makes institutional reform more policy-relevant.

Table 4 presents the results using the first set of variables. The indicators themselves show no significant correlation with inequality after controlling for economic policies and the interactions. However, institutions affect inequality through the relationship between economic policy and income shares. Institutions matter for (i) determining whether openness to trade is mapped into equality or inequality, and (ii) the extent to which government expenditure effectively helps the bottom $90 \%$. As the institutional indicators increase (i.e., institutional quality decreases), the equalizer effect of trade and government expenditure is neutralized and eventually reversed. Conversely, financial development and income tax rates show a significant correlation with inequality along the whole institutional spectrum. These patterns are consistent across the four indicators.

Table 5 presents the results using the second set of variables. The results are noisier given the lack of significant time variation in these institutional indicators. However, in general, the results suggest that high group influence partly cancels out the positive effect that openness to trade and government expenditure have on reducing inequality. This is particularly strong when looking at the business elites (Panel D). Interestingly, both the importance of the agrarian elite (Panel B) and the party elite (Panel C) are directly correlated with more inequality.

Finally, Table 6 presents the results using the third set of variables and confirms the previous results. The degree of socioeconomic-based exclusion (Panel A) importantly shapes the correlation between trade and inequality, in the same direction as in the previous exercises. Exclusion by gender (Panel B) accentuates the positive relationship between financial development and inequality and strongly reverts the equalizer effects of government expenditure. Similar patterns arise when looking at exclusion based on political affiliation (Panel C) and the urban/rural distinction (Panel D).

These results support the general conclusion of the analysis based on predetermined variables: institutions affect inequality, in particular, by shaping the correlations between economic policy and top income shares. This seems to be particularly important for trade openness and government expenditure, the two variables that displayed noisier correlations in the previous section.

\section{Discussion and conclusions}

In this paper, I provide evidence on (i) a significant correlation between pre-tax income inequality and economic policy after controlling for country and time fixed effects and economic development, and (ii) an important role for institutions in mediating these correlations, especially for trade openness and government 


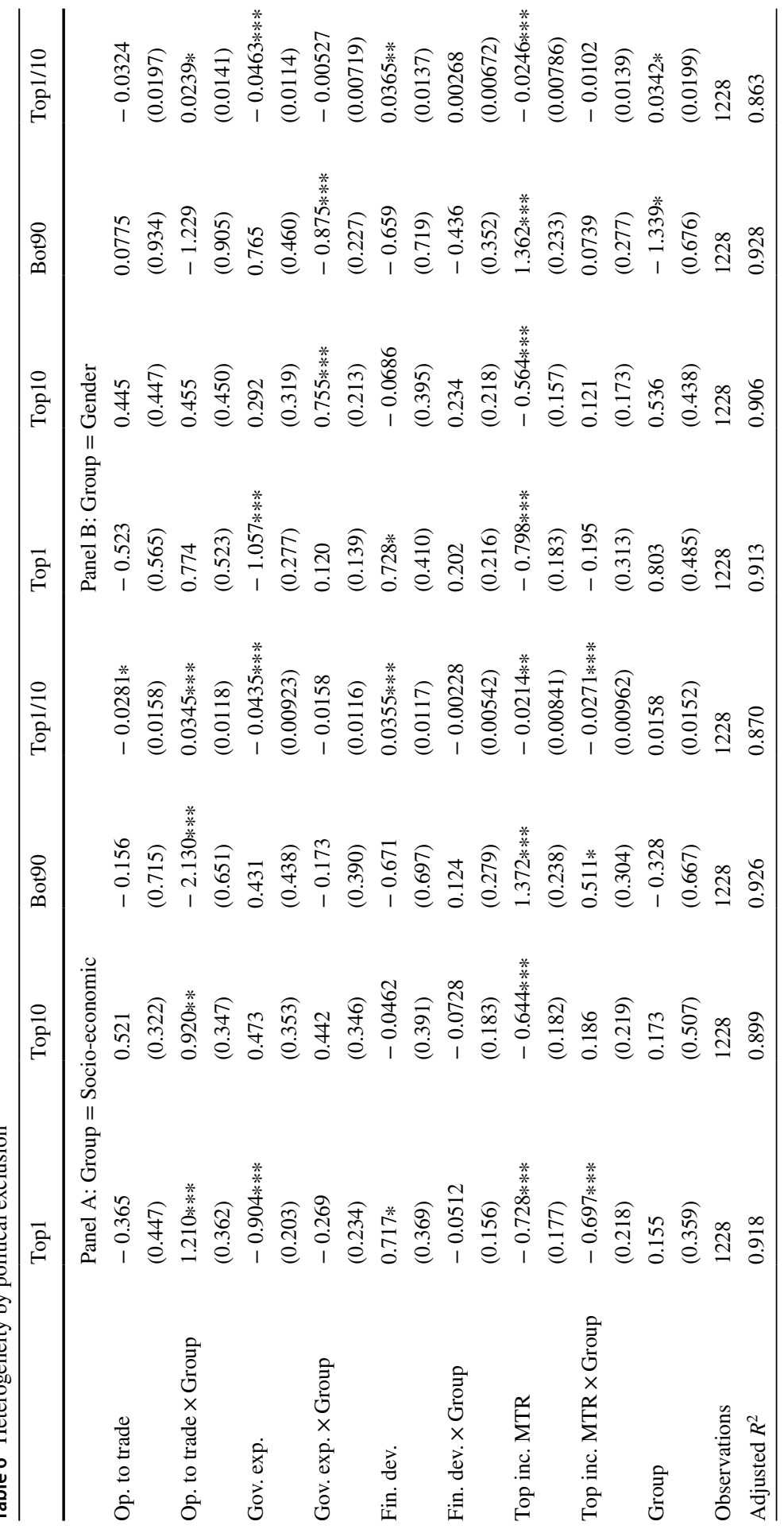




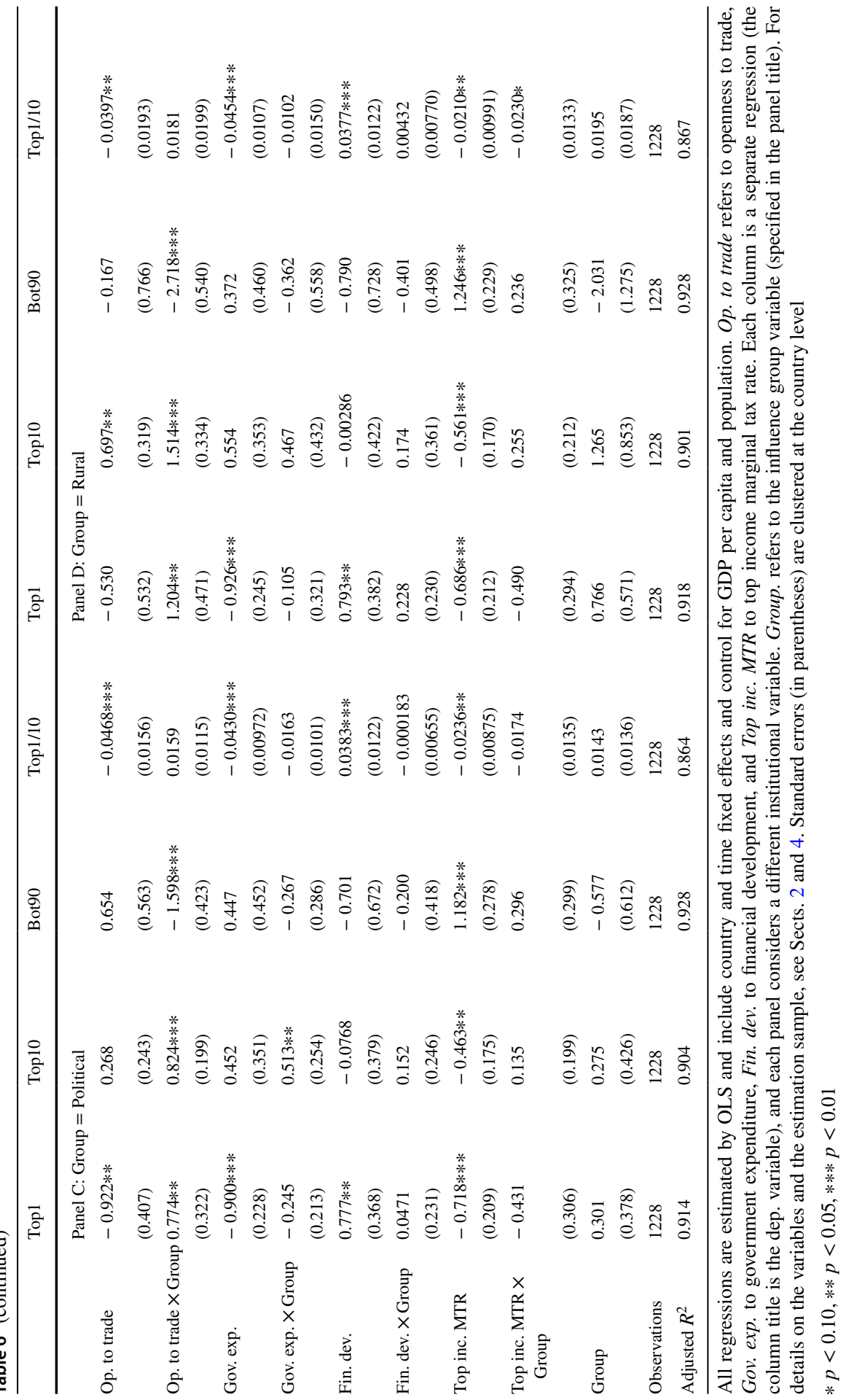


expenditure. These results contest the hypothesis that inequality is an inevitable consequence of growth and technical change.

Since I do not claim causality in my results, I do not take a strong stand on the concrete mechanisms that drive the correlations and the heterogeneities. However, given the institutional variables chosen, my results are consistent with the political economy literature that argues that elites (and other socially powerful groups) exert (non-productive) efforts to increase their share of the pie, potentially at the expense of other social groups, to the extent that the institutional framework allows them to do that (e.g., Acemoglu and Robinson 2000, 2008; Acemoglu 2006; Chaudhry and Garner 2007; Acemoglu et al. 2011, 2015). ${ }^{13}$

This narrative can rationalize the results and stresses the importance of accounting for institutional quality when thinking of optimal policy problems. If institutions are weak, the costs faced by the elite to appropriate the benefits of a policy implementation will be low. The government will implement redistributive policies (e.g., means-tested transfers funded by progressive taxation) to correct for this distributional shock. However, if institutions are weak, the elite will be able to both avoid and influence these policies toward their interests and, therefore, limit their real distributional impact. Then, institutions will affect how economic policies affect the income distribution, both by affecting who benefits from them and the effectiveness of the redistributive policy. Under this reasoning, the results suggest that the financial sector has some intrinsic characteristics that favor rent-seeking activities by the rich regardless of the institutional environment. This is consistent with Bakija et al. (2012), Bivens and Mishel (2013), Piketty et al. (2014) and Stiglitz (2016).

While I suggest that the role of institutions in allowing rent-seeking provides a narrative for my results, more research is needed to understand the mechanisms through which institutions determine the distributional effects of different economic policies. Of particular importance is to understand the challenges governments face to develop better institutions. Optimal policy problems already recognize that the extent of rent-seeking matters for the optimal tax schedule (e.g., Piketty et al. 2014; Rothschild and Scheuer 2016). However, similar to the message of Slemrod and Kopczuk (2002) and Kopczuk (2005) regarding the taxable income elasticity, the relevant elasticities could be interpreted as policy parameters if the social planner can affect the rent-seeking opportunities. The design of optimal policy is dependent on the quality of institutions so, to the extent that social planners can affect them, the optimal policy problem should incorporate this dimension.

Supplementary Information The online version supplementary material available at https://doi.org/10. 1007/s10797-021-09661-6.

Acknowledgements I thank Simón Ballesteros, Jakob Brounstein, Marina Dias, Patrick Kennedy, Pablo Muñoz, Cristóbal Otero, Emmanuel Saez, Felipe Vial, and Danny Yagan for helpful discussions and

\footnotetext{
13 This literature also recognizes that the problem is dynamic and, therefore, powerful groups also influence institutions to increase the returns to rent-seeking activities in the future, increasing the endogeneity concerns of my empirical results.
} 
suggestions. I also thank Zoya Ali, Caitlin Hartley, Tai Lohrer, Aditi Ramakrishnan, and Peter To for excellent research assitance. Usual disclaimers apply.

Open Access This article is licensed under a Creative Commons Attribution 4.0 International License, which permits use, sharing, adaptation, distribution and reproduction in any medium or format, as long as you give appropriate credit to the original author(s) and the source, provide a link to the Creative Commons licence, and indicate if changes were made. The images or other third party material in this article are included in the article's Creative Commons licence, unless indicated otherwise in a credit line to the material. If material is not included in the article's Creative Commons licence and your intended use is not permitted by statutory regulation or exceeds the permitted use, you will need to obtain permission directly from the copyright holder. To view a copy of this licence, visit http://creativecommons.org/licen ses/by/4.0/.

\section{References}

Acemoglu, D. (2006). A simple model of inefficient institutions. Scandinavian Journal of Economics, 108(4), 515-546.

Acemoglu, D., Johnson, S., \& Robinson, J. A. (2001). The colonial origins of comparative development: An empirical investigation. The American Economic Review, 91(5), 1369-1401.

Acemoglu, D., Naidu, S., Restrepo, P., \& Robinson, J. A. (2015). Democracy, redistribution, and inequality. In Handbook of income distribution (Vol. 2, pp. 1885-1966). Elsevier.

Acemoglu, D., Naidu, S., Restrepo, P., \& Robinson, J. A. (2019). Democracy does cause growth. Journal of Political Economy, 127(1), 47-100.

Acemoglu, D., \& Robinson, J. A. (2000). Democratization or repression? European Economic Review, 44(4-6), 683-693.

Acemoglu, D., \& Robinson, J. A. (2008). Persistence of power, elites, and institutions. American Economic Review, 98(1), 267-93.

Acemoglu, D., \& Robinson, J. A. (2012). Why nations fail: The origins of power, prosperity, and poverty. Crown Books.

Acemoglu, D., Ticchi, D., \& Vindigni, A. (2011). Emergence and persistence of inefficient states. Journal of the European Economic Association, 9(2), 177-208.

Akbari, M., Bahrami-Rad, D., \& Kimbrough, E. O. (2019). Kinship, fractionalization and corruption. Journal of Economic Behavior \& Organization, 166, 493-528.

Alesina, A., Glaeser, E., \& Sacerdote, B. (2001). Why doesnt the US have a European style welfare state? Brookings Papers on Economic Activity.

Alesina, A., Tabellini, G.,\& Trebbi, F. (2017). Is Europe an optimal political area? Working paper.

Alvaredo, F., Atkinson, A. B., Piketty, T., \& Saez, E. (2013). The top 1 percent in international and historical perspective. Journal of Economic Perspectives, 27(3), 3-20.

Alvaredo, F., Chancel, L., Piketty, T., Saez, E., \& Zucman, G. (2018). World inequality report 2018. Belknap Press.

Atkinson, A. B., Piketty, T., \& Saez, E. (2011). Top incomes in the long run of history. Journal of Economic Literature, 49(1), 3-71.

Autor, D. H., Katz, L. F., \& Kearney, M. S. (2008). Trends in US wage inequality: Revising the revisionists. The Review of Economics and Statistics, 90(2), 300-323.

Autor, D. H., Levy, F., \& Murnane, R. J. (2003). The skill content of recent technological change: An empirical exploration. The Quarterly Journal of Economics, 118(4), 1279-1333.

Bakija, J., Cole, A., \& Heim, B. T. (2012). Jobs and income growth of top earners and the causes of changing income inequality: Evidence from US tax return data. Working paper.

Bernhard, M., Jung, D.-J., Tzelgov, E., Coppedge, M., \& Lindberg, S. I. (2017). Making embedded knowledge transparent: How the V-Dem dataset opens new vistas in civil society research. Perspectives on Politics, 15(2), 342-360.

Bivens, J., \& Mishel, L. (2013). The pay of corporate executives and financial professionals as evidence of rents in top 1 percent incomes. Journal of Economic Perspectives, 27(3), 57-78.

Blanchet, T., Flores, I.,\& Morgan, M. (2018). The weight of the rich: Improving surveys using tax data. Working paper. 
Bolt, J., Inklaar, R., de Jong, H., \& Van Zanden, J. L. (2018). Rebasing Maddison: New income comparisons and the shape of long-run economic development. GGDC Research Memorandum, 174, 1-67.

Card, D., \& DiNardo, J. E. (2002). Skill-biased technological change and rising wage inequality: Some problems and puzzles. Journal of Labor Economics, 20(4), 733-783.

Card, D., \& Lemieux, T. (2001). Can falling supply explain the rising return to college for younger men? A cohort-based analysis. The Quarterly Journal of Economics, 116(2), 705-746.

Chaudhry, A., \& Garner, P. (2007). Do governments suppress growth? Institutions, rent-seeking, and innovation blocking in a model of Schumpeterian growth. Economics \& Politics, 19(1), 35-52.

Cheibub, J. A., Gandhi, J., \& Vreeland, J. R. (2010). Democracy and dictatorship revisited. Public Choice, 143(1-2), 67-101.

Chetty, R., Friedman, J. N., Hilger, N., Saez, E., Schanzenbach, D. W., \& Yagan, D. (2011). How does your kindergarten classroom affect your earnings? Evidence from Project STAR. The Quarterly Journal of Economics, 126(4), 1593-1660.

Chinn, M. D., \& Ito, H. (2006). What matters for financial development? Capital controls, institutions, and interactions. Journal of Development Economics, 81(1), 163-192.

Coppedge, M., Gerring, J., Knutsen, C. H., Lindberg, S. I., Teorell, J., Altman, D., Bernhard, M., Fish, M. S., Glynn, A., Hicken, A., Luhrmann, A., Marquardt, K., McMann, K., Paxton, P., Pemstein, D., Seim, B., Sigman, R., Skaaning, S.-E., Staton, J., Cornell, A., Gastaldi, L., et al. (2020). V-Dem Dataset v10. Varieties of Democracy (V-Dem) Project.

Coppedge, M., Lindberg, S., Skaaning, S.-E., \& Teorell, J. (2016). Measuring high level democratic principles using the V-Dem data. International Political Science Review, 37(5), 580-593.

Elkins, Z. (2000). Gradations of democracy? Empirical tests of alternative conceptualizations. American Journal of Political Science, 293-300.

Gennaioli, N., \& Rainer, I. (2007). The modern impact of precolonial centralization in Africa. Journal of Economic Growth, 12(3), 185-234.

Giuliano, P., \& Nunn, N. (2018). Ancestral characteristics of modern populations. Economic History of Developing Regions, 33(1), 1-17.

Haselmann, R., Schoenherr, D., \& Vig, V. (2018). Rent seeking in elite networks. Journal of Political Economy, 126(4), 1638-1690.

Helpman, E. (2017). Globalisation and wage inequality. Journal of the British Academy, 5, 125-162.

ICEPP. (2010). Andrew Young School World Tax Indicators.

Kaplan, S. N., \& Rauh, J. (2013). It's the market: The broad-based rise in the return to top talent. Journal of Economic Perspectives, 27(3), 35-56.

Katz, L. F., \& Murphy, K. M. (1992). Changes in relative wages, 1963-1987: Supply and demand factors. The Quarterly Journal of Economics, 107(1), 35-78.

Kling, J. R., Liebman, J. B., \& Katz, L. F. (2007). Experimental analysis of neighborhood effects. Econometrica, 75(1), 83-119.

Kopczuk, W. (2005). Tax bases, tax rates and the elasticity of reported income. Journal of Public Economics, 89(11-12), 2093-2119.

Lazonick, W., \& Mazzucato, M. (2013). The risk-reward nexus in the innovation-inequality relationship: Who takes the risks? Who gets the rewards? Industrial and Corporate Change, 22(4), 1093-1128.

Leigh, A. (2007). How closely do top income shares track other measures of inequality? The Economic Journal, 117(524), F619-F633.

Levine, R.,\& Renelt, D. (1992). A sensitivity analysis of cross-country growth regressions. The American Economic Review, 942-963.

Londoño-Vélez, J. (2014). War and progressive income taxation in the 20th century. Working paper.

Lührmann, A., \& Lindberg, S. I. (2019). A third wave of autocratization is here: What is new about it? Democratization, 26(7), 1095-1113.

Lührmann, A., Mechkova, V., Dahlum, S., Maxwell, L., Olin, M., Petrarca, C. S., et al. (2018). State of the world 2017: Autocratization and exclusion? Democratization, 25(8), 1321-1340.

Mankiw, N. G. (2013). Defending the one percent. Journal of Economic Perspectives, 27(3), 21-34.

Michalopoulos, S., \& Papaioannou, E. (2013). Pre-colonial ethnic institutions and contemporary African development. Econometrica, 81(1), 113-152.

Milanovic, B., Lindert, P. H., \& Williamson, J. G. (2011). Pre-industrial inequality. The Economic Journal, 121(551), 255-272.

Munck, G. L., \& Verkuilen, J. (2002). Conceptualizing and measuring democracy: Evaluating alternative indices. Comparative Political Studies, 35(1), 5-34. 
Nunn, N. (2009). The importance of history for economic development. Annual Review of Econonimcs, $1(1), 65-92$.

Nunn, N. (2020). The historical roots of economic development. Science, 367, 6485.

Palma, J. G. (2011). Homogeneous middles vs. heterogeneous tails, and the end of the inverted-U: It's all about the share of the rich. Development and Change, 42(1), 87-153.

Piketty, T. (2014). Capital in the 21st century. Harvard University Press.

Piketty, T. (2020). Capital and ideology. Harvard University Press.

Piketty, T., Saez, E., \& Stantcheva, S. (2014). Optimal taxation of top labor incomes: A tale of three elasticities. American Economic Journal: Economic Policy, 6(1), 230-71.

Rocabert, J., Schimmelfennig, F., Crasnic, L., \& Winzen, T. (2019). The rise of international parliamentary institutions: Purpose and legitimation. The Review of International Organizations, 14(4), 607-631.

Rodrik, D. (2012). Why we learn nothing from regressing economic growth on policies. Seoul Journal of Economics, 25(2), 137-151.

Roine, J., Vlachos, J., \& Waldenström, D. (2009). The long-run determinants of inequality: What can we learn from top income data? Journal of Public Economics, 93(7-8), 974-988.

Rothschild, C., \& Scheuer, F. (2016). Optimal taxation with rent-seeking. The Review of Economic Studies, 83(3), 1225-1262.

Saez, E.,\& Zucman, G. (2019). The triumph of injustice: How the rich dodge taxes and how to make them pay. WW Norton \& Company.

Sahay, R., Čihák, M., Ndiaye, P., Barajas, A., Bi, R., Ayala, D., Gao, Y., Kyobe, A., Nguyen, L., Saborowski, C., Svirydzenka, K.,\& Yousefi, S. (2015). Rethinking financial deepening: Stability and growth in emerging markets. IMF staff discussion note.

Sala-I-Martin, X. (1997). I just ran two million regressions. The American Economic Review: Papers and Proceedings, 178-183.

Schulz, J. F. (2020). Kin networks and institutional development. Working paper.

Slemrod, J., \& Kopczuk, W. (2002). The optimal elasticity of taxable income. Journal of Public Economics, 84(1), 91-112.

Stiglitz, J. E. (2016). Inequality and economic growth. In M. Jacobs \& M. Mazzucato (Eds.), Rethinking Capitalism (pp. 134-155). Wiley/Political Quarterly.

Zucman, G. (2015). The hidden wealth of nations: The scourge of tax havens. University of Chicago Press.

Publisher's Note Springer Nature remains neutral with regard to jurisdictional claims in published maps and institutional affiliations. 